\title{
Thomas I. Emerson, Lawyer and Scholar: Ipse Custodiet Custodes
}

\author{
Louis H. Pollak $\dagger$
}

For 40 years, the public law of the United States has been shaped in substantial measure by Thomas I. Emerson. In the 1930's and 1940's, Emerson, as a government lawyer, played a major, ever-growing, and characteristically unadvertised role in the design and implementation of the principal New Deal and war-time regulatory programs. ${ }^{1}$ From the mid-1940's on, Emerson's base of operations has been this Law School: for upwards of 2500 students in his classes, and for thousands of other lawyers and judges across the nation who know him only from the printed page, Emerson has given new dimension to the prevailing themes of constitutional and administrative law-most especially those which protect the fundamental rights of individuals in an intensively regulated society.

Emerson would be the last to acknowledge the magnitude of his scholarly achievements. This does not mean that he revels in selfdeprecation, or that he would disavow his extraordinary work product. What it means is simply that Emerson's chief concern is with the content of what has been accomplished, not with harvesting plaudits. Nonetheless, the record ought to show that two of Emerson's works (Political and Civil Rights in the United States ${ }^{2}$ and The System of Freedom of Expression ${ }^{3}$ ) are more than merely authoritative: they are works which reordered the lines of inquiry for those who have come after.

The works are like the man: intelligent, just, systematic, compre-

$\dagger$ Albert M. Greenfield Professor of Human Relations and Law, University of Pennsylvania.

1. Emerson served in the National Recovery Administration in 1933-34; with the National Labor Relations Board from 1934-40 (with a year in 1936-37 at the Social Security Board); as Special Assistant to the Attorney General in 1940.41; as Associate General Counsel and Deputy Administrator for Enforcement in the Office of Price Administration in 1941-45; as General Counsel of the Office of Economic Stabilization in 1945; and as General Counsel of the Office of War Mobilization and Reconversion in 1945 and 1946.

2. T. Emerson \& D. Haber, Political and Civil Rights in the United States (1952) [hereinafter cited as RIGHTs]. The long and fruitful collaboration between Professors Emerson and Haber is discussed on the next page.

3. T. EMerson, The System of Freedom of Expression (1970) [hereinafter cited as FREEDOM OF EXPRESSION]. 
hensive, solid, quietly inexorable. The patience and stamina which are Emerson's intellectual trademarks are evidenced by the provenance of The System of Freedom of Expression, published in 1970. Emerson first wrote Toward a General Theory of the First Amendment. ${ }^{4}$ Having completed this elaborate conceptual prolegomenon-itself an important book-Emerson sat down and wrote the larger volume. According to Emerson, The System of Freedom of Expression began "as a technical law book on the First Amendment," and then, as he rather understatedly adds, "branched somewhat beyond that." It branched into the major treatise on free speech written in our time. It is a work far more spacious, detailed, analytic and synthesizing than Zechariah Chafee's classic, and enormously influential, book of a generation ago, Free Speech in the United States. ${ }^{6}$

In his Foreword to The System of Freedom of Expression, Emerson says: "My principal debt in the preparation of this book is owed to my collaborator in earlier projects, Professor David Haber of Rutgers Law School."7 The reference does more than acknowledge the intellectual stimulus and insight gained from a brilliant fellow worker. It signifies that The System of Freedom of Expression is a logical sequel to several of the major themes canvassed in the great casebook by Emerson and Haber published in 1952-Political and Civil Rights

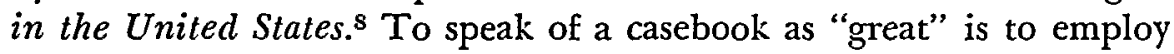
an adjective not generally associated with that art form. But a few casebooks qualify, ${ }^{0}$ and the Emerson-Haber work is surely one: it was the first casebook to bring into systematic lawyerly conjunction the great issues of liberty and equality which lie at the heart of our constitutional processes. The importance of the casebook is underscored when one recalls that it appeared two years before Brown $v$. Board of Education, ${ }^{10}$ and at a time when the late unlamented Joseph McCarthy was at his zenith. ${ }^{11}$ The Foreword to the casebook-written

\footnotetext{
4. T. Emerson, Toward a General Theory of the First Amendient (1966).

5. FREEDOM OF EXPRESSION, supta note 3, at $\mathrm{v}$.

6. Z. Chafee, Free Speech in the United States (1941).

7. FREEDOM OF EXPRESSION, supra note 3, at vi.

8. A fourth edition of Political and Civil Rights is now in press.

9. Another obvious example, published only a year after the Emerson-Haber book, is H. Hart \& H. Wechsler, The Federal Courts and the Federal System (1935, 2d ed. 1973). 10. 347 U.S. 483 (1954).

11. A searing reminder of that era is provided by a state paper not to be found, so far as I know, in any other casebook-the letter written by Lillian Hellman to the House Un-American Activities Committee, in May 1952, in response to a Committee subpoena:

I am ready and willing to testify before the representatives of our Government as to my own opinions and my own actions, regardless of any risks or consequences to myself.

But I am advised by counsel that if $I$ answer the committee's questions about myself, I must also answer questions about other people, and that if I refuse to do so,
} 
by an erstwhile Yale Law Professor, Robert Hutchins-appraised it succinctly: "This is the only comprehensive collection of cases and materials on the most important subject in the world today." 12 What neither Hutchins, nor McCarthy, nor Emerson and Haber knew in 1952 was that the casebook had to a significant degree anticipated the agenda of the remarkable institution which was to commence work a year later-the Warren Court.

\section{II}

In saying that the Emerson-Haber casebook anticipated the Warren Court's agenda I do not mean to be making too spacious a claim. My point is that the casebook identified, and filled in the broad contours of, a large group of extremely important issues which warranted, and thereafter received, Supreme Court scrutiny. Many of them-e.g., school segregation, legislative apportionment, the admissibility of evidence obtained through an unlawful search-were matters the Court had mishandled or skirted in the past. Some-e.g., school prayers-were matters of first impression for the Justices.

So quickly, however, does constitutional doctrine unfold, that some critical issues of the 1960's were not, in 1952, generally perceivedand sometimes not even by Emerson and Haber-as freighted with momentous constitutional implication. One such issue-the scope of the so-called right of privacy-seems to me deserving of some comment, because Emerson, as counsel for appellants in the famous case of Griswold $v$. Connecticut, ${ }^{13}$ was to play a major role in giving the right of privacy constitutional dimension.

The doctrine which Emerson persuaded the Court to constitu-

I can be cited for contempt. My counsel tells me that if I answer questions about myself, I will have waived my rights under the Fifth Amendment and could be forced legally to answer questions about others.

This is very difficult for a layman to understand. But there is one principle $I$ do understand: $\mathrm{I}$ am not willing, now or in the future, to bring bad trouble to people who, in my past association with them, were completely innocent of any talk or any action that was disloyal or subversive.

I do not like subversion or disloyalty in any form, and if I had ever seen any I would have considered it my duty to have reported it to the proper authorities. But to hurt innocent people whom I knew many years ago in order to save myself is, to me, inhuman and indecent and dishonorable.

I cannot and will not cut my conscience to fit this ycar's fashions, even though I long ago came to the conclusion that $I$ was not a political person and could have no comfortable place in any political group.

Rights, supra note 2, at 455. The casebook relates that Hellman's offer "to waive the privilege against self-incrimination and to tell you anything you wish to know about my views or actions, if your committee will agree to refrain from asking me to name other people," was rejected. $I d$.

12. Hutchins, Foreword to RIGHTs, supra note 2, at iii.

13. 381 U.S. 479 (1965). 
tionalize in 1965 was summarized in its entirety, in the 1952 casebook, as follows:

\section{Right of Privacy}

The individual's right to privacy is another restriction on communication recognized by the weight of authority in those jurisdictions where the matter has been considered. This right is invaded by the use in publication or broadcasting of a person's name or likeness without permission. Intrusion into personal affairs such as eavesdropping, examination of probate records or publication of private letters, also violates the right. The police power and the interest of the public to be informed are of course limitations on its scope. See Warren and Brandeis, The Right to Privacy, 4 Harv. L. Rev. 193 (1890) (the classic article that virtually shaped the law). For contemporary discussion and collection of cases see 14 A.L.R.2d 750 (1950); 168 A.L.R. 446 (1947); Ludwig, "Peace of Mind" in 48 Pieces vs. Uniform Right of Privacy, 32 Minn. L. Rev. 734 (1948). See also 13 A.L.R.2d 1213 (1950) and State v. Evjue, 253 Wis. 146, 33 N.W.2d 305, 13 A.L.R.2d 1201 (1948), on the constitutionality of a statute prohibiting the publication of the identity of a female who might have been raped. For analysis of broader issues involved in the right to privacy, see Lasswell, The Threat to Privacy, ch. XI in MacIver (ed.), Conflict of Loyalties (1952).14

Griswold was the third attempt to challenge the constitutionality of the Connecticut criminal statute enacted in 1879 under which "[a]ny person who use[d] any drug, medicinal article or instrument for that purpose of preventing conception"15 was subject to fine and imprisonment. ${ }^{16}$ Appellants Griswold and Buxton, who were respectively the executive director and medical director of a birth control counselling center established by the Connecticut Planned Parenthood League, were convicted of aiding and abetting certain married couples

14. RiGHTs, supra note 2 , at 651 .

15. Act of Mar. 28, 1879, ch. 78, [1879] Conn. Laws 428, repealed by Act of June 26, 1969, Pub. Act 828, [1969] Conn. Laws 1554.

16. Tileston v. Uilman, 318 U.S. 44 (1943), was a declaratory judgment action brought by a physician who alleged that the health of certain of his patients was jeopardized by his inability, because of the challenged statute, to give them the professional advice on birth control methods which they required; the Court held that Dr. Tileston had no standing to assert his patients' Fourteenth Amendment challenge to the statute, and that he had no independent constitutional challenge of his own. Poe v. Ullman, 367 U.S. 497 (1961), was a consolidation of declaratory judgment actions brought by (l) married would-be users of contraceptives who alleged that the statute impinged directly on their own emotional and physical well-being, and (2) Dr. Buxton as the physician of one of the plaintiff patients: the Court dismissed the appeals, holding that decades of nonprosecution meant that the statute was in effect a dead letter, which "deprives these controversies of the immediacy which is an indispensable condition of constitutional adjudication." Id. at 508. Justices Douglas, Harlan and Stewart dissented from the dismissal; the first two of the dissenters also spoke to the merits, finding the use statute unconstitutional. 
in the use of contraceptives. The chief architect of the litigation was Fowler Harper, for many years a distinguished member of the Yalc Law School Faculty. After Griswold's and Buxton's convictions were affirmed by the Connecticut Supreme Court of Errors, Harper prepared to appeal the convictions to the Supreme Court. But as the appeals were docketed in Washington, Harper became gravely ill; knowing that he was dying, he asked Emerson, his colleague and friend, to take over the case.

\section{A. Lawyer Emerson's Dilemma}

But what arguments was Emerson to make to the Court? He could contend, as indeed he did, that the aiding-and-abetting prosecution, based as it was on appellants' counselling of the birth control center's patients, infringed appellants' free speech rights. But unless the Court could be persuaded of the invalidity, at least as to married persons, of the underlying statutory ban on the use of contraceptives whose violation appellants had counselled, the free speech claim was likely to seem perfunctory and insubstantial. ${ }^{17}$ So the central problem of advocacy, once standing had been established, ${ }^{18}$ was to develop a persuasive ground for challenging the use statute.

To assert that the statute offended the Fourteenth Amendment's Due Process Clause presumably meant contending that marital immunity from state prohibitions on the use of contraceptives was part of the "liberty" protected by the Amendment. But to find analogies in support of such a contention, one was forced to go back to uncomfortable pre-1937 precedents. Since 1937, the year Justice Black had joined the Court, no state law had been voided on due process grounds unless it had been found to transgress one or another of the "specific" guarantees of the Bill of Rights-free exercise of religion, freedom

17. Cf. Giboney v. Empire Storage \& Ice Co., 336 U.S. 490,498 (1949);

It has rarely been suggested that the constitutional freedom for speech and press extends its immunity to speech or writing used as an integral part of conduct in violation of a valid criminal statute. We reject the contention now.

18. The problem here was that of demonstrating the appellants' standing to present the claims of married patients harmed by the usc statute. But since the appellants in Griswold were defendants, not persons who had invoked the judicial process, it was not hard to make a case for their entitlement to assert the invalidity of the use statute as it affected those to whom they had given professional advice on how to violate the statute. For standing purposes, in short, it was proper to regard appellants as surrogates for the nonparties they had counselled; and the Court would in due course so hold. Compare Barrows v. Jackson, 346 U.S. 249 (1953) (upholding the right of a white seller sued for breaking a racially restrictive housing covenant by selling to a black buyer to assert the constitutional rights of the black buyer to be free of such covenants), and NAACP v. Alabama, 357 U.S. 449 (1958) (holding that the NAACP could represent and assert the constitutional rights of its members), with Tileston v. Ullman, 318 U.S. 44 (1943) (discussed in note 9 supra). See Note, Standing to Assert Constitutional Jus Tertii, 88 HARv. L. REv. 423 (1974). 
of speech, the privilege against self-incrimination, assistance of counsel, etc. To be sure, only Justice Black was committed to the view that Fourteenth Amendment "liberty" (and/or "privileges and immunities") was shorthand for, and hence confined by, the first eight amendments. Justice Douglas felt "liberty" included those amendments, but was not limited to them. ${ }^{10}$ Their Brethren, although slower than Justices Black and Douglas to "incorporate" all of the eight amendments into "liberty," were also unwilling to regard "liberty" as a closed category no broader than the amendments. At the far pole, Justice Harlan, most cautious about "incorporation," was insistent on the continuing vitality of Justice Cardozo's equation of the Due Process Clause with those values which are "of the very essence of a scheme of ordered liberty."20 But the equation was anathema to Justices Black and Douglas, and worrisome to other members of the Court, insofar as it seemed to invite the Justices to go back to the pre-1937 habit of reading their own views of social policy into the Fourteenth Amendment.

Against this background, how should a lawyer argue to the Court that a statute which offended none of the guarantees of the Bill of Rights was nevertheless so onerous a curtailment of values of describable constitutional dimension as to warrant judicial invalidation? Emerson could argue-and he did-the moral myopia which had given rise to the statute; the moral arrogance which maintained it; the statute's incompatibility with contemporary mores; its baneful impact on the marital relationship; its harm to the physical and emotional health of wife and husband; and its prospective harvest of unwanted children. But to say all this was simply to demonstrate the statute's insolence and unwisdom-propositions better suited to testimony before a legislative committee than argument before an appellate court. How to give these propositions constitutional weight remained something of a conundrum.

Three years before (in Griswold's early stages, following the demise of the second court challenge to the Connecticut use statute ${ }^{21}$ ), Norman Redlich had described the advocate's problem in such a case in the following terms:

19. It was long supposed that Justice Douglas, who joined Justice Black's historic dissent in Adamson v. California, 332 U.S. 46, 68 (1947), shared Justice Black's apparent unwillingness to read $\$ 1$ of the Fourteenth Amendment "liberty" more broadly than the first eight amendments (by contrast with Justices Murphy and Rutledge, who dissented separately in Adamson, id. at 123,124$)$. But Justice Douglas ultimately espoused a broader reading; see his dissent in Poe v. Ullman, 367 U.S. at 516.

20. Palko v. Connecticut, 302 U.S. 319, 325 (1937). On the same page of Palko, Justice Cardozo used the more frequently remembered phrase, "the concept of ordered liberty."

21. Poe v. Ullman, 367 U.S. 497, 500 (1961). 
[F]or one who feels that the marriage relationship should be beyond the reach of a state law forbidding the use of contraceptives, the birth control case poses a troublesome and challenging problem of constitutional interpretation. He may find himself saying, "The law is unconstitutional-but why?" There are two possible paths to travel in finding the answer. One is to revert to a frankly flexible due process concept even on matters that do not involve specific constitutional prohibitions. The other is to attempt to evolve a new constitutional framework within which to meet this and similar problems which are likely to arise.22

Professor Redlich pursued the latter course. His "new constitutional framework" was the long-ignored Ninth Amendment. That Amendment, as most of us do not recall, provides as follows: "The enumeration in the Constitution, of certain rights, shall not be construed to deny or disparage others retained by the people." Redlich urged, in effect, that immunity from governmental interference with the sexual aspects of the marriage relationship should be regarded as among the rights "retained by the people."

- There were numerous problems with this approach, however, and the "new constitutional framework" seems to me more ingenious than persuasive. The stubborn fact is that the Ninth Amendment, like the prior eight amendments, is a specification of individual rights as against the United States, not as against the states. Specifically, the Ninth Amendment was intended to be responsive to what Madison regarded as "one of the most plausible arguments I have ever heard urged against the admission of a bill of rights into this system," namely, that "a bill of rights . . . by enumerating particular exceptions to the grant of power ... . would disparage those rights which were not placed in that enumeration . ..."23 Whether (putting aside express federal constitutional limitations on the states, such as the bill of attainder and ex post facto clauses) any "rights . . . retained by the people" as against the United States would also be "rights ... retained by the people" as against the states, should have been a matter of state constitutional law, the answer to which would not necessarily have been uniform among the states. As Justice Story said of the Constitution, in commenting on the analogous Tenth Amendment ("The powers not delegated to the United States by the Constitution, nor prohibited by it to the States, are reserved to the States

22. Redlich, Are There "Certain Rights... Retained by the People"?, 37 N.Y.U.L. REv. 787, 798 (1962).

23. 1 AnNals of Cong. 456 (1789) (running head: "Gales \& Seaton's History of Debates in Congress"). 
respectively, or to the people"): "Being an instrument of limited and enumerated powers, it follows irresistibly, that what is not conferred, is withheld, and belongs to the state authorities, if invested by their constitutions of government respectively in them; and if not so invested, it is retained BY THE PEOPLE, as a part of their residuary sovereignty."24

I find Story's explanation of the Tenth Amendment more persuasive than Redlich's yoking of the Tenth and Ninth: "The last four words of the Tenth Amendment must have been added to conform its meaning to the Ninth Amendment and to carry out the intent of both-that as to the federal government there were rights, not enumerated in the Constitution, which were 'retained ... by the people,' and that because the people possessed such rights there were powers which neither the federal government nor the states possessed."25 If I understand Redlich's thesis, his "must have been"

24. 2 J. Story, Commentaries on the Constitution of the United States 625 (4th ed. 1873).

25. Redlich, supra note 22 , at 807 . In the paragraph preceding the quoted paragraph, Redlich argues that since "the Tenth Amendment was not intended to restrict the states, the last four words have meaning only if they were intended to impose additional restrictions on the federal government." $I d$. This is of course a possible meaning, but it is not the only possible meaning: as Justice Story's commentary suggests, the reservation of powers to "the people" (as an alternative to "the states") serves as a reminder that it is not the function of the federal Constitution to distribute powers as between each state and its own residents.

The legislative history of "or to the people" does little to resolve the ambiguity; but the history is not quite as meager as Redlich seems to suppose, and what there is does not, in my judgment, cut in favor of Redlich's interpretation. It is true, as he points out, that we have no record of the Senate debate, and that the Tenth Amendment came to the Senate without the phrase. Yet in fact, as Goebel showed in the course of his meticulous reconstruction of the adoption of the Bill of Rights, the phrase originated in, and was twice approved by, the House of Representatives-notwithstanding which, the addition never appeared in the Journal of the House. $1 \mathrm{~J}$. Goebel, History OF THE Supreme Court OF THE UNITEd STATES: ANTECEDENTS AND BeginNings to 1801 , at 439,442 (197I). The two brief snatches of House debate do not reflect any explicit awareness of a link between the Tenth and Ninth Amendments. What they suggest to me is an eagerness on the part of the proponents of the Bill of Rights to make a cosmetic concession in the wording of the Tenth Amendment in order to soften the rejection of a proposal which would have fundamentally altered the Constitution by precluding federal governmental exercise of implied powers-namely, the insertion of the word "expressly" so that the Tenth Amendment would have read: "The powers not expressly delegated to the United States by the Constitution, nor prohibited by it to the States, are reserved to the States respectively, or to the people."

The first discussion of the matter took place on August 18, 1789, in Committee of the Whole (1 ANNALS OF CoNG. 790 (1789) (running head: "Gales \& Seaton's History of Debates in Congress')):

The 9 th proposition, in the words following, was considered, "The powers not delegated by the Constitution, nor prohibited by it to the States, are reserved to the States respectively."

MIR. TUCKER proposed to amend the proposition, by prefixing to it "all powers being derived from the people." He thought this a better place to make this assertion than the introductory clause of the Constitution, where a similar sentiment was proposed by the committee. He extended his motion also, to add the word "expressly," so as to read "the powers not expressly delegated by this Constitution."

Mr. MADISON objected to this amendment because it was impossible to confine a Government to the excrcise of express powers; there must necessarily be admitted 
assumes that the "rights" which were "retained by the people" were coextensive with the "powers" which were "reserved ... to the people" as against the federal government and the respective state governments. In other words, Redlich's "must have been" appears to assume his hoped-for conclusion-that the Ninth Amendment may be fairly read as having established "rights . . . retained by the people" both against the United States and against the states. Moreover, under this assumption the enlarged scope of the Ninth Amendment is arrived at directly, obviating Redlich's second step-"incorporation" or "absorption" of the Ninth Amendment (and the Tenth) into the Fourteenth Amendment. ${ }^{20}$

Overarching my textual difficulty with Redlich's argument is a larger jurisprudential difficulty. Assuming-and I not only assume but assert-that the history of $\S 1$ of the Fourteenth Amendment, rightly understood, does not tie it wrist and ankle to the first eight amendments and nothing more, ${ }^{27} \mathrm{I}$ then am at a loss to know why

powers by implication, unless the Constitution descended to recount every minutia. He remembered the word "expressly" had been moved in the convention of Virginia, by the opponents to the ratification, and, after full and fair discussion, was given up by them, and the system allowed to retain its present form.

Mr. SHERMan coincided with Mr. Madison in opinion, observing that corporate bodies are supposed to possess all powers incident to a corporate capacity, without being absolutely expressed.

MR. TUCKER did not view the word "expressly" in the same light with the gentleman who opposed him; he thought every power to be expressly given that could be clearly comprehended within any accurate definition of the general power.

MR. TUCKER's motion being negatived,

Mr. Carroll proposed to add to the end of the proposition, "or to the people;" this was agreed to.

On August 21, the House briefly repeated the debate in the Committee of the Whole three days before (id. at 797):

The ninth proposition [what was to be the Tenth Amendment] MIR. GERRX proposed to amend by inserting the word "expressly," so as to read "the powers not expressly delegated by the Constitution, nor prohibited to the States, are reserved to the States respectively, or to the people." As he thought this an amendment of great importance, he requested the yeas and nays might be taken. He was supported in this by one-fifth

of the members present; whereupon they were taken, and were as follows....

YEAS ....17

NAYS .....32

Mr. SherMan moved to alter the last clause, so as to make it read, "the powers not delegated to the United States by the Constitution nor prohibited by it to the States, are reserved to the States respectively, or to the people."

This motion was adopted without debate.

Presumably because Sherman's motion was described as directed "to the last clause," Professor Goebel read it as a motion to add "or to the people." I J. Goebel, supra, at 442. But Gerry's motion clearly presumed that "or to the people" was already part of the draft proposition, which sttggests that the thrust of Sherman's motion may have been stylistic, inserting "to the United States" and reinserting "by it."

26. Redlich, supra note 22 , at 808 .

27. With all deference to Justice Black's Adamson dissent, 332 U.S. 46, 68 (1947), I think Charles Fairman has the better of the historical argument. See Fairman, Does the Fourteenth Amendment Incorporate the Bill of Rights? The Original Understanding, 2 Sran. L. REv. 5 (1949). Compare the concurring opinion of Justice Black, with the dissenting opinion of Justice Harlan, in Duncan v. Louisiana, 391 U.S. 145, 162, lit (1968). 
judges would find it easier to give disciplined content to the Ninth Amendment's unenumerated "rights . . . retained by the people" than to the Fourteenth Amendment's "liberty." The latter may be a semantic battleground, but the former is a trackless wonderland.

\section{B. Lawyer Emerson's Brief}

Thus, however regarded, Redlich's suggestion still left the basic problem: How was a lawyer to locate a "right of privacy" in the Fourteenth and/or Ninth Amendments? This was Emerson's dilemma. But perhaps the dilemma was more apparent than real. He had to use the Fourteenth Amendment, phrasing the argument in various ways in order to accommodate as many schools within the Court as possible. He also, so it seems to me, was bound to use the Ninth Amendment, even if (and I do not know this to be the case) his doubts about its applicability were as substantial as mine. Emerson was, after all, representing clients, not just ideas. He was surely entitled -he was, perhaps, professionally required-to advance an argument seriously propounded by a fellow lawyer-scholar. Redlich's reading of the Ninth Amendment did not, after all, do violence to its text. Whether it was a proper reading depended on larger presuppositions about the meaning of the first ten amendments taken as an aggregate supplement to the Constitution. A priori, Redlich's contentions were certainly no less persuasive than others which had found judicial favor-for example, the inclusion of corporations among "citizens" in Article III; and the incorporation of some, or all, of the first eight amendments in "liberty."

What Emerson did-rightly, in my view-was to deploy the Ninth Amendment, but with caution. It is used among, but ancillary to, the variously formulated Fourteenth Amendment arguments. In Emerson's brief on appeal, Point I develops at great length the folly of Connecticut's ban on the use of contraceptives. ${ }^{28}$ Then, at page 79 , comes Point III:

The Connecticut Anti-Contraceptive Statutes Violate Due Process Of Law In That They Constitute An Unwarranted Invasion of Privacy.

On that page and the four which follow, the supporting arguments are put forward under the following topic sentences:

28. Brief of Appellant at 14, Griswold v. Connecticut, 381 U.S. 479 (1965). 
The Constitution nowhere refers to a right of privacy in express terms. But various provisions of the Constitution embody separate parts of it. And the demands of modern life require that the composite of these specific protections be accorded the status of a recognized constitutional right.

In short, just as the First Amendment, though referring concretely to speech, press, assembly, and petition, protects a general right of expression and association (see NAACP v. Button, 371 U.S. 415 (1963)), so the Third, Fourth and Fifth Amendments, while specifically mentioning only the major forms of invading privacy which were paramount at the time, embody a general principle which protects the private sector of life against "every unjustifiable intrusion by the Government."

It can be argued, further, that the right of privacy is protected by the Ninth Amendment.

Finally, protection against unwarranted intrusion by the government into private affairs is incorporated in the "liberty" guaranteed by the due process clause of the Fourteenth Amendment.

\section{The Court's Response}

The Court's response to Emerson's arguments in Griswold v. Connecticut is well known (if, not surprisingly, somewhat imperfectly understood). Suffice it to recall, in broad terms, the differences in approach reflected in the several opinions filed:

Justice Douglas, speaking for the Court, delivered an opinion of reversal which was joined by Chief Justice Warren and Justices Clark, Brennan and Goldberg. In characterizing the marital interest-the interest which appellants asserted was of constitutional dimensionJustice Douglas described it, apparently interchangeably, as "a right of privacy" (Emerson's terminology) and "an association": "We deal with a right of privacy older than the Bill of Rights . . . an association that promotes . . a bilateral loyalty, not commercial or social projects. Yet it is an association for as noble a purpose as any involved in our prior decisions." 29 In giving that interest constitutional

29. 381 U.S. at 486 . 
dimension, notwithstanding that "[ $\mathrm{t}]$ he association of people is not mentioned in the Constitution, nor in the Bill of Rights" (as Emerson had acknowledged in his brief), Justice Douglas pointed to the Third, Fourth, Fifth, and Ninth Amendments, as Emerson had, and cited the bulk of Emerson's cases: "The foregoing cases suggest that specific guarantees in the Bill of Rights have penumbras, formed by emanations from those guarantees that help give them life and substance. ... The present case, then, concerns a relationship lying within the zone of privacy created by several fundamental constitutional guarantees."30 This being so, the vice of the Connecticut statute, as applied to married couples, lay in "the familiar principle .. . that a "governmental purpose to control or prevent activities constitutionally subject to state regulation may not be achieved by means which sweep unnecessarily broadly and thereby invade the area of protected freedoms.' NAACP v. Alabama, 377 U.S. 288, 307."31 Although Justice Douglas did not find it necessary to identify the "activities constitutionally subject to state regulation," he presumably had in mind Connecticut's policy of barring sexual relationships outside marriage -a policy which, it was argued, a married person might be deterred from violating if it were felt that pregnancy might ensue. ${ }^{32}$.

Justice Goldberg, in an opinion joined by the Chief Justice and Justice Brennan, concurred in Justice Douglas's opinion, and then added, at some length, certain further observations: (1) The Fourteenth Amendment's "concept of liberty protects those personal rights that are fundamental, and is not confined to the specific terms of the Bill of Rights."33 (2) "While the Ninth Amendment-and indeed the entire Bill of Rights-originally concerned restrictions upon federal power, the subsequently enacted Fourteenth Amendment prohibits the States as well from abridging fundamental constitutional liberties. And, the Ninth Amendment, in indicating that not all such liberties are specifically mentioned in the first eight amendments, is surely relevant in showing the existence of other fundamental personal rights, now protected from state, as well as federal, infringement." ${ }^{4}$ (3) "In sum, I believe that the right of privacy in the marital

30. Id. at 484-85.

31. Id. For discussion of NAACP v. Alabama, see p. 65l infra.

32. Counsel for Connecticut relied heavily on the explanation of the policy underlying the use statute advanced by the Supreme Court of Errors in State v. Nelson, 126 Conn. 412, 11 A.2d 856 (1940); and reference was made to Connecticut's fornication and adultery statutes to support the proposition that "Connecticut has statutes restricting several [sic] relations to the married with their spouses..." Brief of Appellee at 15, Griswold v. Connecticut, 381 U.S. 479 (1965).

33. 381 U.S. at 486 .

34. Id. at 493 . 
relationship is fundamental and basic-a personal right 'retained by the people' within the meaning of the Ninth Amendment. Connecticut cannot constitutionally abridge this fundamental right, which is protected by the Fourteenth Amendment from infringement by the States." $3 \bar{s}$

Justice Harlan, concurring separately, restated the Palko view. Justice White, also concurring separately, found the asserted nexus between banning marital use of contraceptives and discouraging extramarital sexual relations too tenuous to support Connecticut's serious impairment of a Fourteenth Amendment "liberty"-namely, the autonomy of the marital relationship.

Justices Black and Stewart each filed a dissent, and each joined the other's dissent. They both condemned the Connecticut use statute on policy grounds. Justice Black thought it "offensive", ${ }^{36}$ Justice Stewart thought it "uncommonly silly." 37 But neither could find a warrant for judicial intervention, except, as Justice Black noted, in the discredited Lochner ${ }^{38}$ view that the Fourteenth Amendment gave the Court a general warrant to monitor the wisdom of state law.

\section{What Does Griswold Signify?}

In The System of Freedom of Expression, five years after Griswold was decided, Emerson had this to say:

In N.A.A.C.P. v. Alabama ex rel. Patterson, the Supreme Court created a new constitutional right that did not as such exist before-the right of association. In Griswold $v$. Connecticut, it established the right of privacy as a newly discovered constitutional right. $^{38}$

Writing five years after the publication of The System of Freedom of Expression, I conclude that Professor Emerson understated the importance of lawyer Emerson's very important victory. Moreover, in hewing too closely to the traditional understanding of the case, his assessment may throw us off the track of Griswold's real significance.

I readily concede that Emerson's verdict-that the Court "established the right of privacy as a newly discovered constitutional right"-is a plausible interpretation of Justice Douglas's majority opinion. But it is not the only plausible interpretation. Moreover, I submit that no

35. Id. at 499 .

36. Id. at 507 .

37. Id. at 527 .

38. Lochner v. New York, 198 U.S. 45 (1905).

39. Freedom of Expression, supra note 3, at 611 . 
plausible interpretation of Justice Douglas's opinion is analytically adequate to the issues presented.

I say so for these reasons: First, as I have already pointed out, the opinion seems to use "privacy" and "association" interchangeably. Second, dictum in Eisenstadt $v$. Baird suggests that "association," not "privacy," is really the controlling concept in Griswold: "It is true that in Griswold the right of privacy in question inhered in the marital relationship. Yet the marital couple is not an independent entity with a mind and heart of its own, but an association of two individuals each with a separate intellectual and emotional makeup. If the right of privacy means anything, it is the right of the individual, married or single, to be free from unwarranted governmental intrusion ...." 40 Third, I would argue that neither "association" nor "privacy" is a word aptly descriptive of a constitutionally protected interest: Each word describes a setting which can be put to good, constitutionally protected use (prayer, writing a declaration of independence) or bad-if the community so determines-governmentally regulable use (price-fixing, constructing a bomb). "Association" and "privacy" are analytically useful only to the extent that, in a particular controversy, protection of the one or the other against state intrusion can be shown to vindicate one or more of the "liberties" protected by the Fourteenth Amendment. Indeed, evidence that these twin (or obverse) concepts are instruments for the vindication of "liberties," but are not themselves "liberties," is afforded by NAACP $v$. Alabama"1 -the case referred to by Emerson as creating "a new constitutional right that did not as such exist before-the right of association." 42 There a unanimous Court, speaking through Justice Harlan, barred Alabama's attempt to compel disclosure of the NAACP's Alabama membership. Although there is language in the opinion which seems to accord "association" independent constitutional status (e.g., "In the domain of these indispensable constitutional liberties, whether of speech, press, or association . . ." 43 ), it seems reasonably clear that the Court saw "association" not as an end in itself but as an instrument adaptable to the achievement of "liberty": "It is beyond debate that freedom to engage in association for the advancement of be-

40. Eisenstadt v. Baird, 405 U.S. 438,453 (1972); cf. Roc v. Wade, 410 U.S. 113, 161, 171, 207, 209, 221 (1973). Of course the Court's opinion in Eisenstadt spoke only for four Justices (including Justice Douglas). In any event, I am not entitled to be overly critical of Emerson for not taking the Eisenstadt dictum into account, in view of the fact that Eisenstadt was decided two years after the publication of The System of Freedom of Expression.

41. 357 U.S. 449 (1958).

42. See p. 650 supra.

43. 357 U.S. at 461 . 
liefs and ideas is an inseparable aspect of the 'liberty' assured by the Due Process Clause of the Fourteenth Amendment, which embraces freedom of speech." 44

Griswold differs from NAACP $v$. Alabama in that the "privacy"or is it "association"?-there protected is not ancillary to the exercise of free speech, or some other one of the rights listed in the first eight amendments. I agree with Justice Stewart's observations that (l) "As to the First, Third, Fourth, and Fifth Amendments, I can find nothing in any of them to invalidate this Connecticut law, even assuming that all those Amendments are fully applicable against the States," 45 and (2) "the idea that a federal court could ever use the Ninth Amendment to annul a law passed by the elected representatives of the people of the State of Connecticut would have caused James Madison no little wonder." 48 But this does not mean that Griswold was wrongly decided. Griswold was rightly decided, and should have been so decided had the first nine amendments never been added to the Constitution. Griswold was rightly decided because, as Justices Harlan, White and Goldberg each showed, the marital relationship is part of the "liberty" secured by the Fourteenth Amendment, and, as Justice White showed, Connecticut's justification for curtailing that liberty in the manner contemplated by the statute was hopelessly unpersuasive. ${ }^{47}$ In short, the convictions of Griswold

44. Id. at 460. Supportive of this reading of NAACP $v$. Alabama (and notable in view of the apparent interchangeability of "privacy" and "association" in the Court's opinion in Griswold) is Justice Harlan's explanation in NAACP $v$. Alabama of the hazard involved in forced disclosure of membership lists: "Inviolability of privacy in group association may in many circumstances be indispensable to preservation of freedom of association, particularly where a group espouses dissident beliefs." Id. at 462 .

45. 381 U.S. at 528 .

46. Id. at 530 .

47. In support of the syllogism, I offer Justice McReynold's vintage "due process" language in Meyer v. Nebraska, 262 U.S. 390, 399-400 (1923):

The problem for our determination is whether the statute, as construed and applied, unreasonably infringes the liberty guaranteed to the plaintiff in error by the Fourteenth Amendment. "No state shall... deprive any person of life, liberty, or property, without due process of law:"

While this court has not attempted to define with exactness the liberty thus guaranteed, the term has received much consideration and some of the included things have been definitely stated. Without doubt, it denotes not merely freedom from bodily restraint, but also the right of the individual to contract, to engage in any of the common occupations of life, to acquire useful knowledge, to marry, establish a home and bring up children, to worship God according to the dictates of his own conscience, and, generally to enjoy those privileges long recognized at common law as essential to the orderly pursuit of happiness by free men.... The established doctrine is that this liberty may not be interfered with, under the guise of protecting the public interest, by legislative action which is arbitrary or without reasonable relation to some purpose within the competency of the State to cffect. Determination by the legislature of what constitutes proper exercise of police power is not final or conclusive but is subject to supervision by the courts.

In the sophisticated retrospection of half a century, we tend to be leery of reliance on pronouncements made by Justice McReynolds, and especially so when he wraps the 
and Buxton were properly reversed, but not for the reasons given in the Court's opinion. As Harry Wellington puts it, in his fine article, "[p]enumbras were not necessary, zones of privacy, an unfortunate invention ...." 48

The Court's opinion in Griswold not only complicated understanding of that case but tended to obscure judicial perception of issues presented in later cases-most notably the issues considered in Roe v. Wade ${ }^{40}$ I think, nonetheless, that in due course we will see Griswold as a reaffirmation of the Court's continuing obligation to test the justifications offered by the state for state-imposed constraints which significantly hamper those modes of individual fulfillment which are at the heart of a free society. The ghost of Lochner prompts caution, but not paralysis. As Justice Frankfurter wrote, in one of his greatest opinions-his concurrence in the Siveezy case, another of lawyer Emerson's important victories-"in the end, judgment cannot be escapedthe judgment of this Court."50

Fourteenth Amendment around various forms of economic activity. And yet $I$ suggest that the quoted paragraphs require no significant qualification now, except to make the point that the state has a very small burden to assume in justifying most restraints on "the right of the individual to contract," and a very heavy burden when it seeks to interfere with "the right... to acquire useful knowledge, to marry, establish a home and bring up children, to worship God according to the dictates of his own conscience." The acquisition of knowledge is a central aspect of the First Amendment's intellectual freedom, just as the worship of God is the paradigm of the First Amendment's religious freedom. For most Americans, marriage is also a sacramental endeavor, not a "contract" of ordinary marketplace dimension; but $I$ would further argue that the degree to which the Constitution defends marriage against unnecessary state intrusions should not depend on the religiosity of the high contracting parties. See Pollak, Public Prayers in Public Schools, 77 HARv. L. REV. 62, 71-73 (1963). In any event, the justification offered by Connecticut for the statute challenged in Griswold was so tenuous that it should not have carried the burden of sustaining a restraint on "the right of the individual to contract" in the conventional marketplace sense.

48. Wellington, Common Law Rules and Constitutional Double Standards: Some Notes on Adjudication, 83 YALE L.J. 221, 294 (1973).

49. 410 U.S. 113 (1973). "Privacy" (to whose constitutionalization Griswold gave such a boost) was uppermost in the Court's mind as it considered Roe $v$. Wade: "This right of privacy, whether it be founded in the Fourteenth Amendment's concept of personal liberty and restrictions upon state action, as we feel it is, or, as the District Court determined, in the Ninth Amendment's reservation of rights to the people, is broad enough to encompass a woman's decision whether or not to terminate her pregnancy." 410 U.S. at 153. "The pregnant woman cannot be isolated in her privacy. She carries an embryo and, later, a fetus...." Id. at 159. But it is hard to see how the concept materially aided analysis: I do not understand how "privacy" assists in resolving what appear to be the crucial issues in the case-the scope and timing of the state's authority to restrict the "woman's decision whether or not to terminate her pregnancy." Why, for example, does the fact that a woman is seven months pregnant-and hence the fetus has achieved "viability"-alter the constitutional balance between the woman's "privacy" and "the State's important and legitimate interest in potential life"? Id. at 150. The Court apparently holds that "privacy" is weightier before "viability" and less weighty thereafter; but the Court's opinion does not seem to explain why.

50. Sweezy v. New Hampshire, 354 U.S. 234, 267 (1957). Economist Paul Sweezy declined to answer questions about the Progressive Party and about the content of a lecture Professor Sweezy had given at the University of New Hampshire. The questions were asked by the New Hampshire Attorney General, whom the state legislature had constituted a one-man investigator of un-New Hampshire activities; Sweezy's contempt 


\section{III}

Wherever democratic principle has led him, Emerson has fought the good fight. Sometimes, as in Griswold and Sweezy, he has gone to court. Often, he has given his time and skills to organizations-or, to use the quasi-constitutionalized term, "associations"-the Progressive Party, ${ }^{51}$ the National Lawyers Guild, ${ }^{52}$ the ACLU, and any number of humbler ad hoc groups. But for the most part he has done battle with a pen and a yellow legal pad, sitting at the long table in his book-piled, bay-windowed office on the second floor of the Law School. For a quarter of a century he has challenged "loyalty" programs, segregation, ${ }^{54}$ the House Un-American Activities Committee, ${ }^{55}$ censorship, ${ }^{56}$ and malapportionment..$^{57}$ And recently he has been a chief architect of the jurisprudential infrastructure supporting the Equal Rights Amendment. ${ }^{58}$ "Over the past generation," as Kenneth Karst

conviction was set aside by the Court. The Court's opinion sidestepped Sweezy's constitutional challenge to the questions by finding that it was uncertain that the questions were within the scope of the authority delegated by the legislature to an executive official, the Attorney General. Justice Frankfurter, joined by Justice Harlan, concurred in the judgment of reversal; they faced up to-and decided in Sweezy's favor-the serious constitutional claims, advanced by Emerson, that the questions unjustifiably intruded on Sweezy's personal political autonomy and on his academic freedom.

When Emerson took the case to the Court he denominated it an "appeal," on the ground that the state statute authorizing the Attorney General's investigation was brought in question. When the Court set the case down for oral argument, the Court noted that it was postponing the question of jurisdiction until the argument on the merits. When he prepared a draft of his brief, Emerson asked me to review the portion addressed to the Court's jurisdiction to insure that he had satisfactorily allayed the Court's jurisdictional doubts. But the first paragraph of the Court's opinion recites that, notwithstanding the Court's reservation of the jurisdictional question until the oral argument, "The parties neither briefed nor argued the jurisdictional question. The appellant has failed to meet his burden of showing that jurisdiction by appeal was properly invoked. The appeal is therefore dismissed. Treating the appeal papers as a petition for certiorari, under 28 U.S.C. $\$ 2103$ (1970), the petition is granted." I do not recall Emerson putting any serious legal questions to me after Sweezy.

51. Emerson's human, nondogmatic approach to politics is illustrated by his agreement to be the Progressive candidate for Governor of Connecticut in 1948, on condition that he might withdraw if-as in fact happened-his friend and one-time chief at OPA, Chester Bowles, was nominated by the Democrats.

52. See, e.g., Emerson, National Lawyers Guild: Legal Bulwark of Democracy, $10 \mathrm{~L}$. GuILD REv. 93 (1950).

53. Emerson \& Helfeld, Loyalty Among Government Employees, 58 YALE L.J. 1 (1948); the article prompted a rebuttal by $J$. Edgar Hoover (id. at 401), which in turn led to a surrebuttal by the authors (id. at 412 ). See id. at 400 (explanation of the editors).

54. See, e.g., Emerson, Frank, Frey, Griswold, Hale, Havighurst \& Levi, Brief for Committee of Law Teachers Against Segregation in Legal Education, 34 MINN. L. Rev. 289 $(1950)$.

55. "It functioned, in short, as a sort of modern Inquisition, attempting to stamp out heresy in the nation." Freedom of Expression, supra note 3, at 251. See Emerson, Answer to the Report of the House Committee on Un-American Activities on the National Lawyers Guild, 10 L. GuILD Rev. 45 (1950). This campaign of Emerson's has also finally been victorious. In January 1975 , the House Internal Security Committee, née HUAC, "passed away." N.Y. Times, Jan. 19, 1975, \$ 4 (The Week in Review), at 20, col. 1. See New YORKER, Jan. 27, 1975, at 31 .

56. Emerson, The Doctrine of Prior Restraint, 20 L. \& ConTeMp. Prob. 648 (1955).

57. See, e.g., Emerson, Malapportionment and Judicial Power, 22 L. IN TRANsimoN 125 (1962), published simultaneously with certain omissions in 62 YALE L.J. 64 (1962).

58. Brown, Emerson, Falk \& Freedman, The Equal Rights Amendment: A Constitu- 
has observed, "the liberal faith in freedom has had no more persistent or persuasive advocate than Professor Emerson." 59

Linking Emerson's many causes are his profound commitment to free inquiry and expression and his equally profound commitment to scrupulous fairness in the management of our institutions; in combination, these are the instruments for protecting the dignity and fostering the fulfillment of each individual member of an open, pluralist society. And the ground rules he has developed for his country are those which govern his own daily round:

A law teacher who was a student of Emerson's in the 1960's recalls the class discussion of Brown $v$. Board of Education. Until Emerson talked about the case, it had never occurred to the student that there was a plausible argument to be made for "separate but equal." And indeed Emerson's treatment of the case was so objective as to leave the student, for a time, somewhat uncertain whether his professor, on balance, approved the decision.

Kathy and I have a somewhat comparable recollection. In 1947, when Emerson was in his second year as a teacher and I was in my second year as a student, he and $I$ took part in a radio debate; together we argued the affirmative of the proposition that the UnAmerican Activities Committee should be abolished. Eight or more years later, after I had returned to New Haven to teach, Kathy and I found a recording of that debate; and one evening we played the recording for my fellow debater. After the record-player had scratchingly evoked the dated eloquence of Professor Emerson and Student Pollak, Kathy got up to turn it off. But she was stopped by a gentle remonstrance: "Kathy, you can't turn it off now, we have to listen to the arguments on the other side." And listen we did.

Emerson is not simply committed to the due process of law. He is addicted to it. Some of the addiction may trace back to Emerson's days as a student at this Law School. Some of it may derive from his first job after graduation, when he worked for Walter Pollak and Carl Stern on Powell v. Alabama, ${ }^{60}$ the first phase of the Scottsboro Cases. ${ }^{B 1}$ But the bulk of it springs from deep within the heart of this quiet man-this consummate lawyer-scholar of relentless integrity.

tional Basis for Equal Rights for Women, 80 YALE L.J. 871 (1971). See Murray, The Rights of Women, in N. DORSEN, THE RIGHTS OF AMERICANS $541-42$ (1970).

59. Karst, Book Review, 46 N.Y.U.L. Rev. 429, 437 (1971).

60. 287 U.S. 45 (1932).

61. The second phase of the Scottsboro Cases-Norris v. Alabama, 294 U.S. 587 (1935), and Patterson v. Alabama, 294 U.S. 600 (1935)-arose after Emerson had left Engelhard, Pollak, Pitcher \& Stern to work for the government. 